Preprint

UCRL-JC-141849

\title{
An Opportunity to Immobilize 1.6 MT or More of Weapons-Grade Plutonium at the Mayak and Krasnoyarsk-26 Sites
}

\author{
L. J. Jardine, G. B. Borisov, S. I. Rovny, K. G. Kudinov, A. \\ A. Shvedov
}

This article was submitted to $8^{\text {th }}$ International Conference on Radioactive Waste Management and Environmental Remediation Bruges, Belgium

U.S. Department of Energy

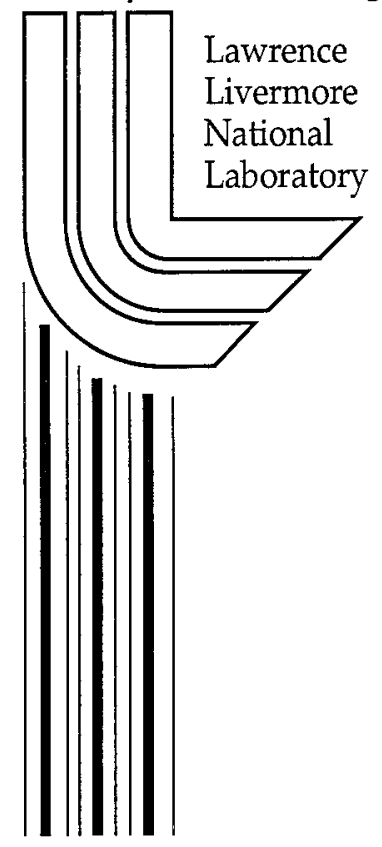

September 30 through October 4, 2001

\section{June 29, 2001}




\section{DISCLAIMER}

This document was prepared as an account of work sponsored by an agency of the United States Government. Neither the United States Government nor the University of California nor any of their employees, makes any warranty, express or implied, or assumes any legal liability or responsibility for the accuracy, completeness, or usefulness of any information, apparatus, product, or process disclosed, or represents that its use would not infringe privately owned rights. Reference herein to any specific commercial product, process, or service by trade name, trademark, manufacturer, or otherwise, does not necessarily constitute or imply its endorsement, recommendation, or favoring by the United States Government or the University of California. The views and opinions of authors expressed herein do not necessarily state or reflect those of the United States Government or the University of California, and shall not be used for advertising or product endorsement purposes.

This is a preprint of a paper intended for publication in a journal or proceedings. Since changes may be made before publication, this preprint is made available with the understanding that it will not be cited or reproduced without the permission of the author.

This report has been reproduced

directly from the best available copy.

Available to DOE and DOE contractors from the

Office of Scientific and Technical Information

P.O. Box 62, Oak Ridge, TN 37831

Prices available from (423) 576-8401

http://apollo.osti.gov/bridge/

Available to the public from the

National Technical Information Service

U.S. Department of Commerce

5285 Port Royal Rd.,

Springfield, VA 22161

http://www.ntis.gov/

OR

Lawrence Livermore National Laboratory

Technical Information Department's Digital Library

http://www.llnl.gov/tid/Library.html 


\title{
An Opportunity to Immobilize 1.6 MT or More of Weapons-grade Plutonium at the Mayak and Krasnoyarsk-26 Sites
}

\author{
Leslie J. Jardine \\ University of California, Lawrence Livermore National Laboratory, USA \\ P.O. Box 808, Livermore, California 94550 \\ 925-423-5032, fax 925-422-8347, e-mail JARDINE1@IInl.gov
}

Georg B. Borisov

A. Bochvar, All-Russian Scientific Institute of Inorganic Materials (VNIINM)

5 Rogov Street, Moscow 123060, Russian Federation

Sergey I. Rovny

Production Association "Mayak"

31, Lenin Street, Ozyorsk, Chelyabinsk region, 456780, Russian Federation

Konstantin G. Kudinov

Mining Chemical Combine (MCC)

53, Lenin Street, Zhelezaogorsk, Krasnoyarsk region, 662990, Russian Federation

Alexander A. Shvedov,

All-Russian Design Research Institute of Complex Power Technology (VNIPIET)

82, Savushkina Street, St. Petersburg 197183, Russian Federation

\begin{abstract}
The Mayak Production Association (PA Mayak), an industrial site in Russia, will be assigned multiple new plutonium disposition missions in order to implement the Agreement Between The Government Of The United States Of America And The Government Of Russian Federation Concerming The Management And Disposition Of Plutonium Designated As No Longer Required For Defense Purposes And Related Cooperation signed September 1, 2000, by Gore and Kasyanov, In addition, the mission of industrial-scale mixed-oxide (MOX) fabrication will be assigned to either the Mining Chemical Combine (MCC) industrial site at Krasnoyarsk-26 (K-26) or PA Mayak. Over the next decades, these new missions will generate radioactive wastes containing weapons-grade plutonium. The existing Mayak and K-26 onsite facilities and infrastructures cannot currently treat and immobilize these Pu-containing wastes for storage and disposal. However, the wastes generated under the Agreement must be properly immobilized, treated, and managed.
\end{abstract}

New waste treatment and immobilization missions at Mayak may include operating facilities for plutonium metal-to-oxide conversion processes, industrial-scale MOX fuel fabrication, BN-600 PAKET hybrid core MOX fuel fabrication, and a plutonium conversion demonstration process. The MCC K-26 site, if assigned the industrial-scale MOX fuel fabrication mission, would also need to add facilities to treat and immobilize the Pu-containing wastes.

This paper explores the approach and cost of treatment and immobilization facilities at both Mayak and K26. The current work to date at Mayak and MCC K-26 indicates that the direct immobilization of $1.6 \mathrm{MT}$ of weapons-grade plutonium is a viable and cost-effective alternative. 


\section{INTRODUCTION}

The US and Russia have been engaged in joint meetings, collaborations, and technical work on various aspects of excess weapons plutonium disposition since the first meeting of technical experts held January 1995 in the United States. Over this six-year period of US Department of Energy (DOE)-funded studies, the Russian plutonium production industrial sites and supporting Institutes have recognized the value of plutonium immobilization and have started the development of appropriate technologies. Current Ministry of Atomic Energy of the Russian Federation (Minatom) policy, however, is to recover weapons-grade plutonium in all process and waste streams to concentrations orders of magnitude below US past practice. The Russian total costs for the new plutonium disposition facilities would be lower with the design and installation of plutonium immobilization technologies than with present plutonium recovery technologies, leading the Russian industrial sites to prefer immobilization over recovery. This provides opportunities to immobilize additional quantities of weapons-grade plutonium for storage and geologic disposal if sources of funding can be arranged to continue development and to implement the immobilization options in Russia.

Currently, numerous contracts are in place between three DOE laboratories (Oak Ridge National Laboratory, Los Alamos National Laboratory and Lawrence Livermore National Laboratory) and Minatom scientific institutes, design organizations and industrial sites to study various aspects of excess weapons plutonium disposition in Russia. Lawrence Livermore National Laboratory (LLNL) is currently the lead DOE laboratory for the topics of plutonium immobilization; packaging and transportation of plutonium metal, plutonium oxide, and fresh MOX fuel assemblies, and MOX spent fuel storage and transportation in Russia. LLNL supports the other DOE laboratories in plutonium conversion and MOX fuel fabrication activities where applicable.

As part of this plutonium disposition effort, LLNL is conducting engineering studies, research and development, and large tests and demonstrations with multiple Russian organizations. The majority of LLNL contracts involve various aspects of immobilization of weapons plutonium-containing materials at the Mayak and Krasnoyarsk-26 industrial sites at Ozersk and Zheleznogorsk, respectively.

This paper summarizes the current immobilization engineering assessments in progress at Mayak and Krasnoyask that are establishing the feasibility of immobilizing over 1.6 MT of excess weapons plutonium into solid matrices, suitable for storage and geologic disposal.

\section{MAYAK SITE}

A new waste treatment facility capable of handling and treating future solid and liquid Pu-containing wastes for the Mayak site is being studied and designed by Russian Minatom organizations under LLNL contracts with US DOE NN-60 funds. An integrated new waste treatment facility is likely to be more cost effective than construction of up to four separate waste treatment systems for four possible new Mayak weapons plutonium disposition missions. The design approach for the new waste treatment facility uses existing Mayak waste treatment systems and facilities to the maximum extent possible so as to minimize costs and construction schedules. However, the plutonium content in these new wastes restricts the use of existing treatment systems in many cases so that some new systems are required.

Because a new waste treatment facility and associated systems must be constructed at Mayak, for only incremental costs, there is an opportunity to provide the technical means to immobilize an additional $1 \mathrm{MT}$ or more of weapons-grade plutonium contained in existing plutonium sludges in storage tanks in Area 954 at Mayak. The total Pu content in the stored sludges is estimated at more than $1 \mathrm{MT}$. The current Mayak plan for these sludges, based on Minatom policy, is to recover the weapons-grade plutonium in the Area 954 tanks by reprocessing and separating into a clean oxide for storage and reuse. This plan exists because current Mayak technologies use the RT-1 radiochemical plant and other process systems to generate discharge waste streams of extremely low concentrations of plutonium, namely below $200 \mathrm{ppm}$ Pu in solids and 50-100 $\mu \mathrm{g} / \mathrm{l}$ in liquids as required by current Russian Federation policies for recovery and discharge limits for weapons-grade plutonium in discharged waste streams [1-5]. These existing plutonium sludges cannot be sent directly to the new EP-500 melter for vitrification due to nuclear criticality 
and other facility and process design constraints due to the complex chemical constituents involved in these sludges.

Therefore, the design assessment of the new Mayak waste treatment facility includes an option to immobilize the plutonium sludges from the Area 954 tanks into a form suitable for storage and geologic disposal with no further separation of weapons-grade plutonium for storage and reuse. Russian research to date indicates that forms in which plutonium can most effectively be immobilized are certain glass or glass-like materials. The immobilization option, if implemented, would remove $1 \mathrm{MT}$ or more of weaponsgrade plutonium from weapons useable forms by satisfying the so-called 'spent fuel standard' for immobilization, as first defined in the National Academy of Sciences Report [6], and thus contribute to the non-proliferation goals of both countries. The spent fuel standard would be achieved because of the dilute nature of the plutonium in the solid matrix $(<<200 \mathrm{ppm})$ and the presence of uniformly distributed gammaray emitting fission products in the solid matrix.

The engineering assessments underway in LLNL contracts will estimate the specific solid and liquid waste streams requiring treatment from metal conversion, MOX fabrication, the BN-600 PAKET hybrid core MOX fabrication and pilot conversion demonstration processes. Initial technical and economic feasibility (TEF) studies will use the estimated solid and liquid Pu-containing waste streams for the metal-to-oxide conversion process and for MOX fuel fabrication to design and size the minimum integrated new waste treatment facility as the baseline option. A second design option for the new facility to be compared with the baseline case is also being developed. This option adds the facility capabilities required to immobilize the plutonium sludges containing 1 MT or more of weapons-grade plutonium. Comparisons of the two design options, with and without the plutonium sludge immobilization, using the developed capital and operating costs, provide the bases for estimating the additional costs required to immobilize the plutonium sludges at Mayak as part of the new Mayak waste treatment process facility and avoid the separation and accumulation of an additional $1 \mathrm{MT}$ or more of weapons-grade oxide in the Russian Federation stockpiles.

\section{Cost estimates for Mayak: assumptions, status and approach}

A single integrated waste treatment and immobilization building is being assessed for the Mayak site. It is envisioned that solid and liquid wastes from the plutonium conversion activities (both pilot and industrial scale) can form the basic requirements for designing the building. It is assumed that for little incremental cost, the immobilization building functions can be modified to treat and immobilize both the MOX fabrication wastes from the industrial-scale facility (if sited at Mayak) and the PAKET facility for the BN600 hybrid core needs and the existing Pu-containing sludges being studied in a TEF. The detailed definition of these incremental costs is now underway.

Figure 1 summarizes the functional arrangements of the design of the proposed new waste treatment building. Zone 1 contains the general receiving, inspection and shipping functions for solid wastes, including space for process consumables, monitoring, and inventory measuring equipment. Zone 2 contains the glovebox facilities for sorting solid wastes into combustible and non-combustible wastes and an incinerator for combustible wastes to make ash for immobilization in Zone 4. Zone 3 contains the systems for decontaminating, packaging, and compacting the non-combustible wastes and space for maintenance of equipment. Plutonium-containing wastes generated in Zone 3 such as liquids and exchange resins are either sent to Zone 4 for immobilization or to Zone 2 for incineration prior to immobilization. Zone 4 contains the main immobilization equipment for liquids and incinerator ash in a hot cell facility including evaporators, melters, remote equipment maintenance space, and off-gas treatment systems required to immobilize liquid Pu-containing wastes, and the plutonium with fission products. Any organic liquids are sent to Zone 2 for incineration or other treatment. Zone 5 contains the space for shielded storage of solidified, packaged, immobilized Pu-containing wastes from Zone 3 and Zone 4, including any necessary cooling requirements for the plutonium sludge and high-americium 


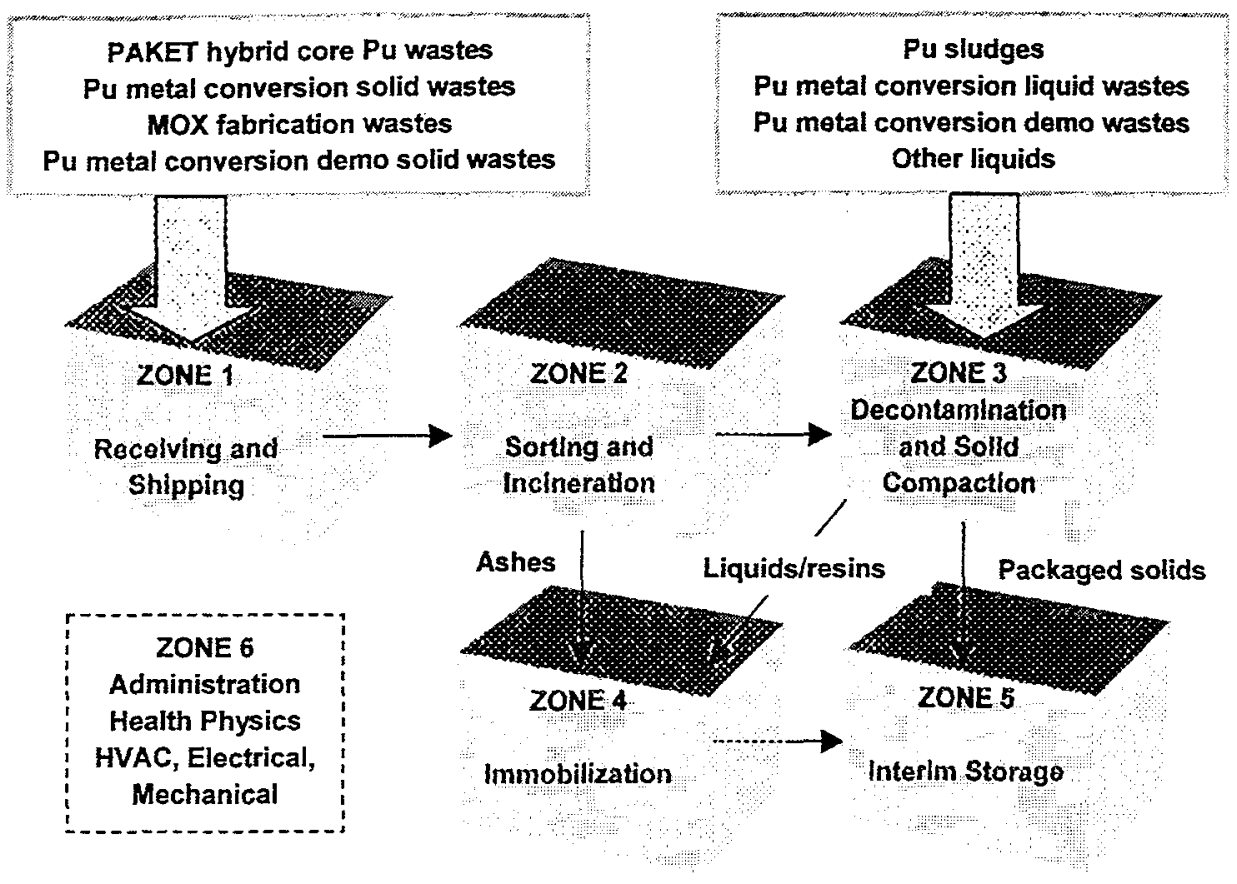

Fig. 1. Functional zones in central Pu waste treatment building at Mayak.

wastes. Zone 6 contains the change rooms, administration offices, and health physics work areas in a standard construction building. The second level of the building is used for mechanical, HVAC, and electrical equipment.

The first engineering step, the TEF, for the Mayak site plutonium immobilization activities for immobilizing about $1 \mathrm{MT}$ of weapons plutonium in existing radiochemical plant sludges is underway. The TEF will compare the recovery and extraction of the $1 \mathrm{MT}$ of weapons plutonium with direct immobilization options using technologies provided by the V.G. Khlopin Radium Institute (KRI), a scientific production association, and the A. A. Bochvar All-Russia Scientific Research Institute of Inorganic Materials (VNIINM), a state science center. Comparisons will be based on economics, environmental impacts, secondary wastes, and radiation exposures performed by the All-Russian Design Research Institute of Complex Power Technology (VNIPIET) and Mayak.

An integrated TEF study of how to treat and immobilize MOX fabrication waste from the industrial-scale facility, if sited at Mayak and not K-26, is getting underway. The Scientific Research and Design Institute of Installation Technology (GSPI) will develop estimates of solid and liquid Pu-containing waste streams based on past Russian MOX fuel fabrication experience at Paket and Granite and past engineering studies. KRI and VNIINM will use these results to provide technologies for immobilizing these Pucontaining wastes. VNIPIET will prepare the integrated TEF designs and perform the comparative assessments.

The plutonium conversion immobilization TEF for Mayak is now being defined. This TEF study is a critical element because Mayak has been selected as the site for the plutonium conversion mission and it has been recognized that the treatment and immobilization of the Pu-containing conversion wastes is a critical first activity. Prompt assessments of waste treatment and immobilization are preferred so that information can be provided back to the plutonium conversion processes, and used to optimize designs for both the main conversion process and for waste treatment. 
Very preliminary capital cost estimates have been made for an integrated Pu-containing waste treatment and immobilization building at Mayak for three types of Pu-containing wastes (Table I). These costs are provided in relative units due to their preliminary nature but absolute estimates have been made. The relative cost for a similar building at Mayak that could accommodate the plutonium sludges in addition to the plutonium conversion and MOX fabrication wastes is 1.5 times higher than the baseline (Table I), largely because Mayak and VNIPIET both believe the design requirements will require a hot cell type construction for the plutonium-conversion wastes, not a glovebox type construction.

Table I. Relative costs of Mayak integrated Pu-containing waste immobilization building. ${ }^{\text {a }}$

\begin{tabular}{|l|c|}
\hline \multicolumn{1}{|c|}{ Immobilization facility } & $\begin{array}{c}\text { Capital and engineering costs as } \\
\% \text { of Mayak baseline }\end{array}$ \\
\hline Only Pu conversion and MOX wastes & 100 \\
\hline All: Pu conversion wastes, MOX wastes, Pu sludges (1 MT Pu) & 150 \\
\hline Only Pu sludges (1 MT Pu) & 110 \\
\hline
\end{tabular}

${ }^{a}$ These initial cost estimates are preliminary; they will be refined during the ongoing TEF studies.

Thus the difference or incremental capital cost is about $50 \%$ more to immobilize an additional 1 MT of weapons-grade plutonium in existing sludges at Mayak. If this immobilization is not done, the Mayak plan is to recover the $1 \mathrm{MT}$ of plutonium from the sludges as oxide and return the weapons plutonium to storage and back to the Russian Federation stockpiles. These very preliminary cost numbers should be carefully used until the engineering contract work is brought to an orderly conclusion, followed by review and approval by the Russian Federation. The logic and top-level schedule being followed for the Mayak site are summarized in Fig. 2. Milestone dates are from the September 1, 2000, Gore and Kasyanov Agreement.

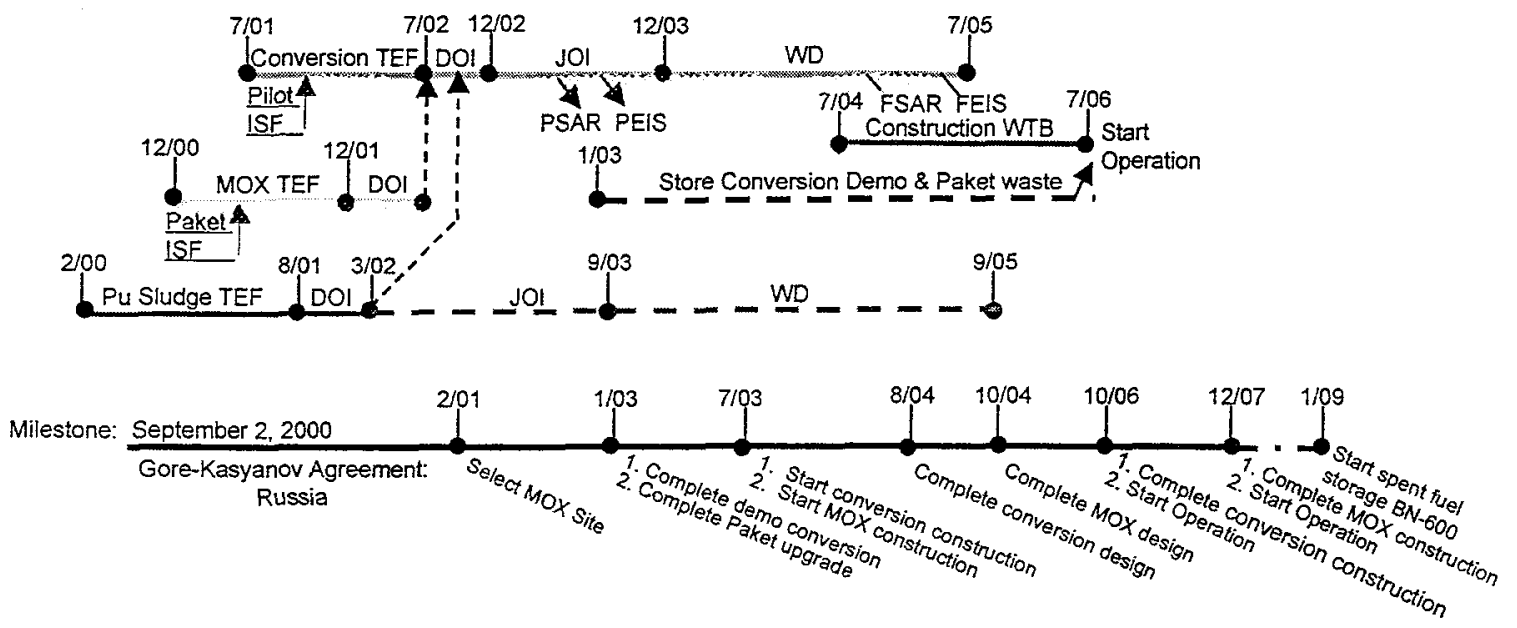

Fig. 2. Logic and top-level schedule for the Mayak site. 


\section{KRASNOYARSK-26 SITE}

If Minatom should select K-26 for the industrial-scale MOX fabrication mission rather than Mayak, a new waste treatment facility would need to be constructed at K-26. This would be an opportunity to provide the technical means to immobilize an additional 0.6 MT of weapons-grade plutonium contained in the existing $6000 \mathrm{~m}^{3}$ of plutonium sludges in storage tanks in Areas 83,84 , and 86 . The plutonium sludges can be treated and immobilized in the same immobilization facility designed for MOX Pu-containing wastes. This could be done at only incremental costs if a new waste treatment facility is required for MOX fabrication at $\mathrm{K}-26$.

The K-26 site joint plutonium immobilization activities are in the third Russian Federation engineering step for new nuclear projects, the Justification of Investment (JOI). The JOI is being built on two previously completed engineering studies and steps, the TEF and the Declaration of Intent (DOI). These previous DOE NN-60 funded studies assessed the recovery and extraction of the $600 \mathrm{~kg}$ of weapons plutonium in the K-26 radiochemical plants and compared this option with direct immobilization options. it was determined by the TEF and JOI that recovery of plutonium from the sludges should not be pursued due to unacceptable economic or environmental impacts, secondary wastes or radiation exposures when compared to the direct immobilization of the Pu-containing sludges. As a result, two direct immobilization options for the Pu-containing sludges are being developed in the JOI. The design work on the plutonium recovery systems at K-26 has been stopped. The Institutes, KRI, and VNIINM are providing the immobilization technologies to the design team of VNIPIET, All-Russian Research and Design Institute of Production Engineering (VNIPIPT), and MCC K-26. Scientific Research and Design Institute of Installation Technology (NIKIMT) is also providing melter technology assistance to the MCC team.

The ongoing $\mathrm{JOI}$ design assessment of the $\mathrm{K}-26$ new plutonium sludge immobilization facility will include an option to immobilize all the MOX fabrication Pu-containing wastes together with the plutonium sludges from the K-26 tanks into a form suitable for storage and geologic disposal with no further separation of weapons-grade plutonium for storage and reuse. This immobilization option, if implemented, would remove $600 \mathrm{~kg}$ or more of weapons-grade plutonium from weapons useable forms. It would satisfy the spent fuel standard as in the Mayak discussion by the combination of very dilute plutonium and distributed gamma-ray emitting fission products in a solid matrix, and contribute to the non-proliferation goals of both countries.

The engineering assessments underway in LLNL contracts will estimate the specific solid and liquid waste streams requiring treatment from the MOX fabrication processes. Initial estimated solid and liquid Pucontaining waste streams for MOX fuel fabrication will be used to design and size the minimum required integrated new waste treatment facility as the baseline option for $\mathrm{K}-26$. A second design option for the new facility to be compared with the baseline case is being developed in the current JOI. The second case adds the MOX fabrication Pu-containing wastes to the new K-26 facility capabilities required to immobilize the $6000 \mathrm{~m}^{3}$ of plutonium sludges containing $600 \mathrm{~kg}$ or more of weapons-grade plutonium. The two design options for MOX fabrication waste immobilization are compared with and without the plutonium sludge immobilization, using the developed capital and operating costs. This provides the basis for estimating the additional costs required to immobilize the plutonium sludges at K-26 as part of the new K-26 waste treatment process facility, and thus avoid the separation and accumulation of an additional $600 \mathrm{~kg}$ or more of weapons-grade oxide in the Russian Federation stockpiles. Maximum use is made of the existing K-26 radiochemical plant systems and infrastructures to minimize costs.

\section{Cost estimates for K-26: assumptions, status and approach}

The third engineering step, the $\mathrm{JOI}$, is progressing on schedule for the $\mathrm{K}-26$ site plutonium immobilization activities. No detailed engineering assessments have been initiated to date for providing immobilization technologies for MOX fabrication Pu-containing wastes at K-26. Only some preliminary MCC K-26 funded scoping studies of waste treatment systems for MOX fabrication have been completed to date. Very preliminary capital cost estimates have been made for an integrated Pu-containing waste treatment and immobilization building at the MCC for those two types of Pu-containing wastes (Table II). 
Table II. K-26 Integrated Pu-containing waste immobilization building cost estimate. ${ }^{\mathrm{a}}$

\begin{tabular}{|l|c|}
\hline \multicolumn{1}{|c|}{ Immobilization facility } & $\begin{array}{c}\text { Capital and engineering costs as } \\
\% \text { of K-26 baseline }\end{array}$ \\
\hline Only MOX wastes & 100 \\
\hline All: Pu sludges $(600 \mathrm{~kg} \mathrm{Pu})$ and MOX wastes & 150 \\
\hline Only Pu sludges $(600 \mathrm{~kg} \mathrm{Pu})$ & 140 \\
\hline
\end{tabular}

${ }^{2}$ These initial cost estimates are necessarily preliminary and will be refined during ongoing TEF and JO/ studies.

These costs are provided in relative units due to their preliminary nature but absolute estimates have been made. Cost estimates have been made to provide a stand-alone waste treatment facility for only MOX fabrication wastes in the underground K-26 facilities using current Russian Federation standards. A TEF is urgently needed for this case and will be undertaken should Minatom select the MCC for the industrialscale MOX fabrication mission.

The total cost estimates for existing plutonium sludge immobilization, without any MOX fabrication wastes, developed during the TEF and the DOI for all engineering, design construction, equipment large-scale engineering testing, and start-up testing result in a cumulative cost of 1.4 times, or $40 \%$ more than for a new facility to treat and immobilize only the MOX fabrication wastes. The hot radioactive startup is scheduled for early 2005. This modest cost increase and rapid schedule are possible because the maximum use is being made of existing MCC K-26 radiochemical plant systems and infrastructures.

During the $\mathrm{JOI}$, the plutonium immobilization system design for weapons plutonium sludges is being modified so as to accept future MOX fabrication Pu-containing wastes should the Russian Federation site the industrial-scale MOX facility at the MCC K-25 site. This requires the addition of facilities for sorting solid wastes, an incinerator for combustible MOX production wastes, and some modifications and additions to the melter feed preparation areas. Metallic non-combustible wastes also require some additions. The total cost for adding this MOX fabrication waste immobilization capability to the JOI design is only $10 \%$ more than the cost for only the plutonium immobilization of only Pu sludges (Table II). The total capital cost is 1.5 , or $50 \%$ more than the estimated cost for the MCC baseline case. The construction schedule for the plutonium sludge immobilization does not change from a 2005 start-up date. It is necessary to start the plutonium sludge immobilization before the MOX Pu-containing wastes become available because the operating period for sludge immobilization is 13 years. The cost estimates (Table II) should be carefully used and are not considered final until the engineering contract work is brought to an orderly conclusion, including review and approval by the Russian Federation. The logic and top-level schedule being followed for the Krasnoyarsk site is summarized in Fig. 3. Milestone dates are from the September 1, 2000, Gore and Kasyanov Agreement.
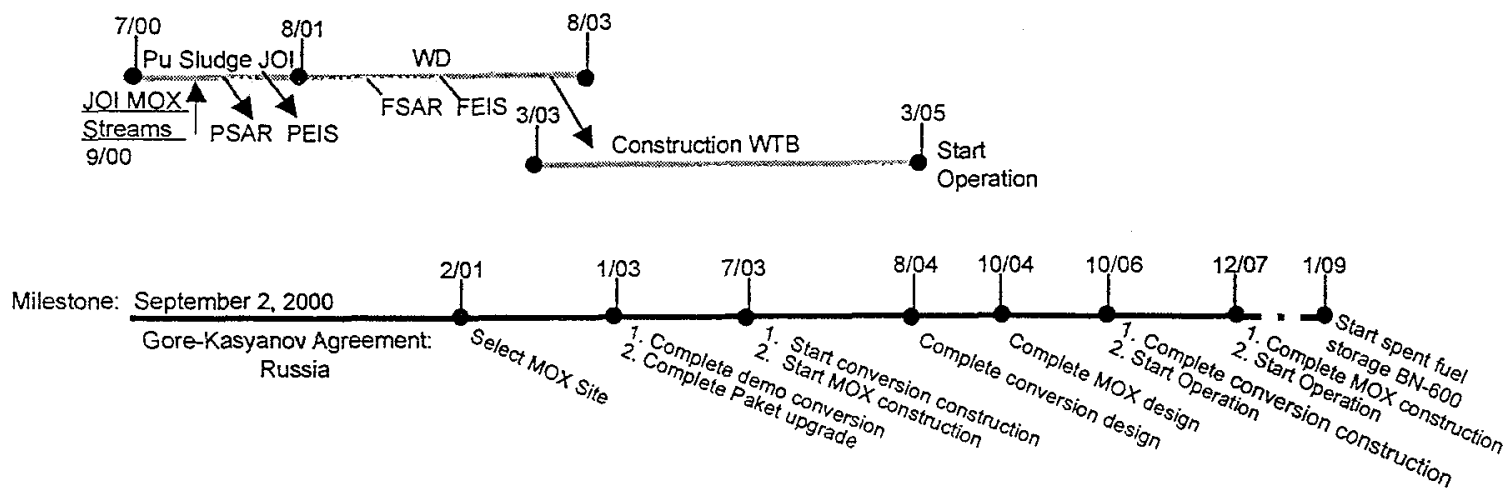

Fig. 3. Logic and top-level schedule for the Krasnoyarsk site. 


\section{CONCLUSIONS}

The Russian plutonium production industrial sites and supporting institutes have developed and recognized, with US DOE funded studies, the value and role of plutonium immobilization technologies compared to the current Minatom policy of weapons-grade plutonium recovery to concentrations orders of magnitude below US past practice. The Russian total costs for the new plutonium disposition facilities are lower with the design and installation of plutonium immobilization technologies than with the plutonium recovery technologies required by current Minatom policy. The Russian industrial sites now know this fact and prefer immobilization technologies. This provides opportunities to immobilize additional quantities of weapons-grade plutonium. The current studies at Mayak and MCC K-26 are considering the direct immobilization of 1.6 MT of weapons-grade plutonium as an alternative to recovery as oxide for storage and reuse.

\section{ACKNOWLEDGMENTS}

Work performed under the auspices of the U.S. Department of Energy by Lawrence Livermore National Laboratory under Contract W-7405-ENG-48.

\section{REFERENCES}

1. Jardine, L. J., Borisov, G. B., and Mansourov, O. A., "Stabilization and Immobilization of Excess Weapons Origin Plutonium," ANS Third Topical Meeting on DOE Spent Nuclear Fuel and Fissile Materials Management, Sept. 8-11, 1998, Charleston, SC, UCRL-JC-129790, Lawrence Livermore National Laboratory, Livermore, CA, 1998.

2. Jardine, L. J., Borisov, G. B., and Mansourov, O. A., "Immobilization of Excess Weapons Plutonium in Russia," Waste Management 1999 Conference, Feb. 28-March 4, 1999, UCRL-JC-132920, Lawrence Livermore National Laboratory, Livermore, CA, 1999.

3. Jardine, L. J., and Borisov, G. B., Excess Weapons Plutonium Immobilization in Russia: A Review of LLNL Contract Work, Lawrence Livermore National Laboratory, Livermore, CA, UCRL-ID-138361, April 15, 2000.

4. Jardine, L. J., Revenko, Y. A., Kudinov, K. G., Tretyakov, A. A., Vassilyev, A. V., Borisov, G. B., Nazarov, A. V., Aloy, A. S., Shvedov, A., and Gusakov, B. V., "Technical and Engineering Feasibility Study of the Vitrification of Plutonium-Bearing Sludges at the Krasnoyarsk Mining and Chemical Combine by Means of Microwave Heating," American Nuclear Society Topical Meeting DOE Spent Fuel and Fissile Materials Management June 4-8, 2000, San Diego, CA, UCRL-JC-136383, Lawrence Livermore National Laboratory, Livermore, CA, 2000.

5. Gupalo, T. A., Anderson, E. B., Jardine, L. J., "Status of Geologic Disposal and Isolation in Russia for Plutonium-Containing Wastes of Military Programs," Disposal Technologies and Concepts International Conference on Radioactive Waste Disposal, Sept. 4-6, 2000, Berlin, Germany, UCRL-JC-138202, Lawrence Livermore National Laboratory, Livermore, CA, 2000.

6. Management and Disposition of Excess Weapons Plutonium, National Academy of Sciences Committee on International Security and Arms Control, Washington, DC, 1994. 


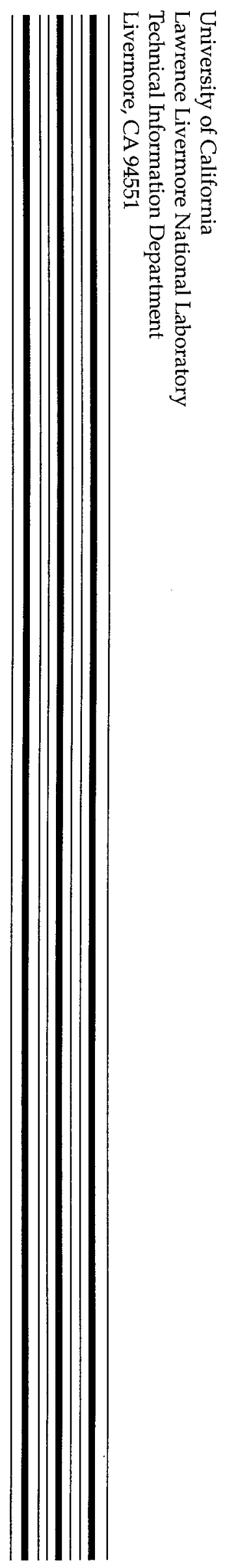

